\title{
EFFECTS OF AGE, SIZE, SPONSOR AND GOVERNMENT SHAREHOLDINGS ON PROFITABILITY: EVIDENCE FROM ENGINEERING INDUSTRY OF BANGLADESH
}

DOI: 10.17261/Pressacademia.2020.1222

JBEF- V.9-ISS.2-2020(9)-p.171-181

\section{Md. Atiqullah Khan}

University of Dhaka, Dept. of Finance, Dhaka, Bangladesh. writetoatiq@gmail.com, ORCID: 0000-0002-4704-5594

Date Received: April 9, 2020

Date Accepted: June 16, 2020

To cite this document

Khan, M. A., (2020). Effects of age, size, sponsor and government shareholdings on profitability: evidence from engineering industry of Bangladesh. Journal of Business, Economics and Finance (JBEF), V.9(2), p.171-181.

Permanent link to this document: http://doi.org/10.17261/Pressacademia.2020.1222

Copyright: Published by PressAcademia and limited licensed re-use rights only.

\section{ABSTRACT}

Purpose- This paper aims at investigating the effects of age, size, fixed assets utilization, sponsor and government shareholdings on the profitability of engineering industry of Bangladesh for the period of 2000-2019.

Methodology- This paper analyzed 37 out of 39 companies under engineering industry listed on Dhaka Stock Exchange. Fixed effects model has been applied after deciding this from Hausman test to estimate the effects of age, size, fixed asset utilization, sponsor and government shareholdings on the profitability.

Findings- Size, fixed asset utilization, and sponsor shareholding have significant impact on profitability. While fixed asset utilization has positive impact and age, size, sponsor shareholding and government shareholding have negative impact on it. Mixed influences of learning effect and size effect are experienced among the firms.

Conclusion- The findings from the analysis are diversified in nature. The investors and policy makers should have in depth insight to make better decision.

Keywords: Age effect, size effect, shareholding, profitability, engineering.

JEL Codes: D21, G32, L25

\section{INTRODUCTION}

Engineering industry is the emergent promising sector which can farther broaden the export diversity of Bangladesh by light engineering sector. Engineering industry contributes to all other sectors for example, construction sector, railway sector, automobile sector, paper and pulp sector, pharmaceutical sector, marine sector of Bangladesh. Thus light engineering industry has drawn the attention of the policymaker as a potential cost cutting sector in the near future through providing almost $50 \%$ of the substitutes of all the relevant imported items of Bangladesh. A study conducted by Japan International Cooperation Agency (JICA) showed that there are around 40,000 small-scale light engineering enterprises are producing about to 10 thousand different items for construction, agriculture, and other industries in Bangladesh ("Light Engineering Sector Bangladesh", 2020).

For a long period of time, two questions have been arisen. First one is whether the older firms make higher profits than the younger firms. It's expected that the more a firm grows older, the more the firm learns and increases the profitability (Ilaboya and Ohiokha, 2016). But study shows that age effect doesn't help to increase the profitability of firm (Pervan, Pervan and Ćurak, 2017). The effect of age on the profitability of the firms under engineering industry of Bangladesh is still unknown. Thus the effect of learning by doing on the performance of these firms is a topic of investigation.

The second question is whether the profitability of larger firms is higher than the profitability of smaller firms in terms of total assets as a proxy of size. Study shows that, the size of firms helps to increase productivity (Pagano and Schivardi, 2003). In opposite of the findings, study also shows that size effect doesn't have considerable impact on the firm in making higher profit (Abeyrathna 
and Priyadarshana, 2019). How much the older firms suffer because of 'liability of obsolescence' and 'liability of senescence' helps to understand the size effect on the profitability but it's still unclear in engineering industry of Bangladesh. So there is another lack of knowledge to investigate the size effect on the profitability of the engineering industry of Bangladesh.

The utilization of fixed assets and the shareholding patterns are supposed to have impacts on profitability. But the fixed assets utilization doesn't impact profitability (Ani, 2014). It's examined that shareholding pattern of managerial ownership of the firm influences the firm value (Rizqia, Aisjah and Sumiati, 2013) but Mollah, Al Farooque and Karim (2012) found that major ownership patterns including sponsor shareholding, government shareholding are destructive to the financial performances of the firms and also added that the firm performances are improved by dispersed ownership.

Mixed empirical results were found regarding the impacts of age, size, fixed asset utilization, sponsor shareholding and government shareholding on the profitability of the firm. From the context of developing countries, insufficient empirical work is found regarding these factors.

The inconsistencies among the findings from previous researches are an indication of inconclusive nature of the impacts of these variables. Additionally, it's experienced that the relationship between the size and the profitability of firm was actually industry specific (Becker-Blease, Kaen, Etebari and Bauman, 2010). Thus main purpose of this paper is to investigate the relationship of age, size, fixed asset utilization, sponsor shareholding, government shareholding, institutional shareholding on the profitability of the firms which are running operations under engineering industry of Bangladesh. The findings after conducting the study show that age, size, sponsor shareholding and government shareholding have negative impact and fixed asset utilization has positive impact on the return on assets as a measurement of profitability of the engineering industry of Bangladesh.

An overview of the previous studies and the findings of these are discussed in second part of this paper. Third part discusses about the data and methodology and fourth part of the paper briefly discusses about the analysis and findings of this research. Fifth part provides a complete investigation of learning effect and size effect on profitability. The ending of the paper includes conclusion and recommendations for policy makers and investors.

\section{LITERATURE REVIEW}

The theory of learning by doing hypothesis is a big area of interest in finance and accounting literature. Navaretti, Castellani and Pieri (2012) investigated that the firms having higher ages are less likely to grow fast although they face shrinking probability more than the younger firms. They also concluded that a combination of learning and willingness to grow makes the path of firm growth. Later Coad, Daunfeldt and Halvarsson (2015) conducted an analysis to understand the relationship between the age of frim and the sales growth. It was found that for new ventures, age has positive autocorrelation while it has negative relation for the older firms. The main reasons behind the difference in scenario by age are the environmental turbulence, challenges in adapting the strategies to the changing market conditions. Thus the older firms face more troubles than the newer firms in managing these issues.

On the contrary, by analyzing 302 non-financial firms listed on Borsa Istanbul for a period of 2005-2014, Akben-Selcuk (2016) showed that there exists a negative and convex relationship between the firm age and ROA as profitability. The younger firms face a decrease in profitability but they may become profitable in an old age. In accordance with that the performance of the business firm is negatively correlated with the age of the firm after analyzing 956 firms under Croatian food industry during 20052014 (Pervan et al., 2017). They also showed that size, solvency, liquidity are also influential factors on the profitability of the firms.

Cowling and Tanewski (2018) experimented that not all firm growths will lead to productivity gains. There is significant difference in the way of adding value creation between the small and large firms. The efficiency of the firm follows an inverted $U$ shaped in accordance with firm age and it was found that the youngest (having the age of (0-2 years) and the oldest firms (having the age more than 9 years) are less likely to be more productive than the middle aged firms. But Coad (2016) found that the age effects are occurred with the first 5-7 years. Finally, Oyelade (2019) examined that total sales and age of the firms have significant impact on the return on assets since the incorporation while the age of firm has a negative impact and total sales revenue has a positive impact.

The effect of size on firm's profitability is also another big area of interest. Positive and robust relationship is found between the average firm size and the growth after conducting the study by Pagano and Schivardi (2003). They also found that larger size of firm fostered productivity growth because of taking advantage of the increasing returns related with Research and Development. 
Later, Becker-Blease, Kaen, Etebari and Bauman (2010) examined the relationship between the size of firm and the profitability of the firm in U.S. manufacturing industries and found that profitability increases at a decreasing rate and eventually it declined for 47 of the industries. No relationship was found between the size of firm and profitability up to 52 industries among 109 industries. Only for 11 industries, it was seen that profitability increased with the size of the firm. From this analysis, it's derived that the relationship between the size and the profitability of firm is actually industry specific.

But John and Adebay (2013) discovered that the firm size both in terms of log of total assets and the log of sales had a positive impact on the profitability of the manufacturing companies of Nigeria by considering return on assets as the benchmark to understand profitability. Again Hui, Radzi, Jenatabadi, Kashim and Radu (2013) investigated the relationship of organizational innovation, organizational learning on the organizational performance by picking 168 manufacturing companies under food industry from China, Malaysia and Taiwan. It was explored that firm age and size are the moderating variables by controlling the relationship among organizational learning, innovation and performance.

Kartikasari and Merianti (2016) examined 100 manufacturing companies listed on Indonesia Stock Exchange in a period of 20092014. They discovered that leverage measured by debt ratio has a significant positive impact while total assets as size has a significant negative impact on the profitability represented by return on assets (ROA). Turnovers of the firm doesn't have significant effect on it. But llaboya and Ohiokha (2016) analyzed the effect of firm age, size on the profitability by the panel data after choosing 30 firms from a period of 2006-2012 listed on Nigerian Stock Exchange. Log of profit before interest and tax was chosen as dependent variable for understanding profitability. They stated that firm age and firm size have positive impact on the profitability. The significant positive impact of firm age is an evident of learning by doing hypothesis. Again the significant positive relationship between firm size and profitability denied the structural inertia hypothesis. Fareed, Ali, Shahzad, Nazir and Ullah (2016) too examined the impacts of some key determinants of the profitability of 16 listed firms under power and energy sector of Pakistan for a period off 200-2012. They found that firm growth, size, and electricity crisis positively influence the profitability while age, financial leverage negatively influence the profitability. Productivity and size are found to be the strongest determinants of the profitability in this sector.

Isık, Aydın Unal and Unal (2017) examined the impact of firm size on the profitability by selecting 112 publicly listed companies under manufacturing sector in Turkey from the period of 2005 to 2013. The results from the estimation suggested that the firm size measured through the assets, turnover, no. of employees tends to have a positive influence on profitability by the control variables which are firm age, growth opportunities, liquidity level, financial risks, unsystematic risk. But Abeyrathna and Priyadarshana (2019) examined that the size of the firms doesn't have considerable impact on the profitability of the listed manufacturing business firms in Sri Lanka.

Proper utilization of fixed assets is a key factor to increase profitability of the firm. Varied findings are seen regarding the fixed assets utilization on firm's profitability. Ani (2014) showed that fixed assets turnover impact on returns on equity and not on returns on assets by considering some manufacturing companies listed on Muscat Securities Market. But Warrad and Omari (2015) found that there fixed asset turnover ratio doesn't have significant impact on the returns on assets of service sectors. Same outcome was found by Okwo, Okelue and Nweze (2012) that investment in fixed assets doesn't have strong impact on the profitability of the brewery firms in Nigeria.

Little empirical work is found regarding how sponsor shareholding and government shareholding impact on the profitability of the firm. Cho and Kim (2007) explored that managerial ownership didn't have significant moderating effects on corporate performance of the firms of Korea. Mollah et al. (2012) explored whether different ownership structure, board characteristics variables influenced the firm performance by considering all the firms listed on Botswana Stock Market for a period of $2000-2007$. Surprisingly it was found that all the major ownership patterns like sponsor shareholding, institutional shareholding, government shareholding, foreign shareholding are destructive to the financial performances of the firms. Dispersed ownership improved the firm performances and mitigated the agency conflicts. It was also seen that the performance of firm in Botswana was industry specific instead of firm specific risks and size to explain firm performance.

In accordance with that Stančić, Čupić and Obradović (2014) examined the impacts of board and the ownership structure on the profitability of 74 commercial banks of South east Europe for a period of 2005-2010. It was found that board size has significant negative impact on bank's profitability while the proportion of independent directors' negative impact is not significant. The privately hold domestic banks outperform the state owned banks and foreign banks. Size and capitalization also influence the profitability. Liu (2018) discovered that the government shareholding is likely to be largest block holders and when the government is the largest block holder, the size of its ownership is also quite big. But Makhlouf, Laili, Basah and Ramli (2017) examined the 
effectiveness of the board of directors and the firm performance. It was experienced that the ownership of the board of directors has a positive impact on the profitability of firm where ROA was chosen for a benchmark of profitability.

\section{DATA AND METHODOLOGY}

\subsection{Data}

For constructing the panel dataset, 37 companies out of 39 companies listed on Dhaka Stock Exchange under engineering industry have been chosen. The period of the data is $2000-2019$ for the previously listed companies and for the companies listed later, it's from the year of listing to the year 2019. Because of unavailability and postponing the business operations, a few years of observations were omitted from this unbalanced panel dataset.

\subsection{Dependent Variable}

Return on Assets (ROA): The Return on Assets (ROA) is a great measurement to understand the profitability of any business firm. ROA indicates how profitable the business is by comparing the net income and the total assets of the firm. In this study, ROA has been used for measuring the profitability.

Returns on Assets $(\mathrm{ROA})=$ Net Income/ Total Assets

\subsection{Independent Variables}

Age: The age of a firm indicates how long the firm has been running its business operations. Over the period of time, business firm gets experienced about how to conduct business operations prudently. Thus the age of firm has an active influence on the profitability of the business firm. Instead of the listing year, the year of commencement of the business firm has been used as the age of the firm.

Age of Firm= Since the Year of Commencement of Business Operations

Size: The size of the firm is an important fundamental characteristic of any business firm. The total assets of the firm are a measurement of understanding the size of this firm. The natural log of the total assets has been used as the size of the firm in the study.

Size of Firm $=$ Log of Total Assets

Fixed Asset Utilization: How much the business is generating the revenues by investing into fixed assets can be understood by fixed asset utilization ratio. Thus fixed asset utilization has been used is this study to understand the efficiency of the firm by its impact on the profitability of the firm.

Fixed Asset Utilization $=$ Sales $/$ Fixed Assets

Sponsor Shareholding: Sponsor shareholding indicates the percentage of share in shareholding pattern held by the sponsors of the firm. Sponsor shareholders work for building up the business firm for generating more profits. The change in sponsor shareholding is a strong sign of change in profitability of the business firm.

Sponsor Shareholding = Total No. of Shares Held by Sponsors $/$ Total No. of Shares of the Company

Government Shareholding: Government shareholding indicates the percentage of share in shareholding pattern held by the government. Both in developed and developing countries, government ownership is widely existing. It's highly likely that the business performance is influenced when there exists higher government shareholding.

Government Shareholding = Total No. of Shares Held by Government/ Total No. of Shares of the Company

\subsection{Model and Estimation}

Multiple regression analysis has been used in the study to examine the impacts of age, size, fixed asset utilization and shareholding pattern which includes sponsor shareholding and government shareholding on the profitability of the firm. The following equation expressed in econometric form has been developed based on the variables used in this study for conducting the test:

$\mathbf{R O A}_{i, t}=\boldsymbol{\alpha}+\boldsymbol{\beta}_{1}{ }^{*}$ Age $+\boldsymbol{\beta}_{2}{ }^{*}$ Size $+\boldsymbol{\beta}_{3}{ }^{*}$ Fixed Asset Utilization $+\boldsymbol{\beta}_{4} *$ Sponsor Shareholding $+\boldsymbol{\beta}_{5} *$ Government Shareholding $+\boldsymbol{\varepsilon}_{i, t}$ 
Where the dependent variable, ROA (Returns on Assets) = Net Profit/ Total assets,

$\alpha=$ Constant value (value of net profit when all independent variables are zero)

$\beta_{1}$ to $\beta_{5}$ all are the slopes of the independent variables of the regression

$\varepsilon=$ Error (normally distributed error term with an assumed mean value of 0 ),

$\mathrm{i}=$ company, $\mathrm{t}=$ covered time period

The impacts of the independent variables are tested by using the statistical tools in Stata version 13.0 and EViews 9. To understand the central tendency and the dispersions of data, descriptive statistics are used with the help of correlation analysis. To understand the appropriate model specification in between fixed effects model and random effects model, Hausman test is used. The test suggests that fixed effect model is appropriate for this study.

\section{FINDINGS AND DISCUSSIONS}

\subsection{Descriptive Statistics}

The descriptive statistics of the study provides the central tendency of the variables in Table 1. The mean of ROA (Returns On Assets) is $4.21 \%$ with a minimum value of $-12.12 \%$ and a maximum value of $23.54 \%$. The average age of firm is 27.95 years with a minimum of 4 years and a maximum of 67 years based on the commencement of the business operations. For measuring the size of the firm, logarithm value of total assets was used. The average size of the firm indicates the value of total assets is BDT 4,321 million with a minimum value of BDT 12.19 million and a maximum value of BDT 91,067.18 million. The fixed asset utilization ratio indicates an average of 7.21 times with a minimum value of 0.04 time and a maximum value of 265.56 times. The average shareholding pattern of the sponsors is $36.49 \%$ with a minimum and maximum range of $0.00 \%$ to $80.00 \%$. The average shareholding pattern of the government indicates $8.68 \%$ with a minimum of $0.00 \%$ to a maximum of $65 \%$.

Table 1: Descriptive Statistics

\begin{tabular}{lccccc}
\hline \multicolumn{1}{c}{ Variable } & Obs. & Mean & St. Dev & Minimum & Maximum \\
\hline Return on Assets & 422 & 4.21 & 4.93 & -12.12 & 23.54 \\
Age of Firm & 422 & 27.95 & 13.96 & 4 & 67 \\
Log of Total Assets & 422 & 9.08 & 0.73 & 7.09 & 10.96 \\
Total Assets (in Million) & 422 & 4,321 & 9,307 & 12.19 & $91,067.18$ \\
Fixed Asset Utilization & 422 & 7.21 & 22.46 & 0.04 & 265.56 \\
Sponsor Shareholding & 422 & 36.49 & 22.04 & 0 & 80 \\
Govt. Shareholding & 422 & 8.68 & 19.46 & 0 & 65 \\
\hline
\end{tabular}

\subsection{Correlation}

The correlation matrix among the variables are shown in Table 2. The correlation matrix of the study indicates the value of 1.00 which indicates perfect correlation within variables which is expected. The other correlation coefficients in the study is low which means of having no multicollinearity problem.

Table 2: Correlation Coefficients

\begin{tabular}{|c|c|c|c|c|c|c|}
\hline Variable & 1 & 2 & 3 & 4 & 5 & 6 \\
\hline (1) Return on Assets & 1.00 & & & & & \\
\hline (2) Age of Firm & -0.03 & 1.00 & & & & \\
\hline (3) Log of Total Assets & 0.03 & 0.16 & 1.00 & & & \\
\hline (4) Fixed Asset Utilization & 0.33 & 0.18 & -0.08 & 1.00 & & \\
\hline (5) Sponsor Shareholding & 0.10 & 0.00 & 0.15 & -0.20 & 1.00 & \\
\hline (6) Govt. Shareholding & -0.01 & 0.15 & -0.03 & 0.29 & -0.70 & 1.00 \\
\hline
\end{tabular}




\subsection{VIF and Multicollinearity}

The Variance Inflation Factor (VIF) is a great measurement to understand the multicollinearity in the tests. Table 3 shows that none of the values is above 2.16 where if the value raises above 10.0 is considered to have multi-collinearity problem. That means no problem of multicollinearity exists in the regression variables.

Table 3: VIF Test

\begin{tabular}{lcc}
\hline Variable & VIF & 1/VIF \\
\hline Age of Firm & 1.10 & 0.91 \\
Log of Total Assets & 1.07 & 0.93 \\
Fixed Asset Utilization & 1.13 & 0.88 \\
Sponsor Shareholding & 2.07 & 0.48 \\
Govt. Shareholding & 2.16 & 0.46 \\
\hline Mean VIF & 1.51 & \\
\hline
\end{tabular}

\subsection{Heteroskedasticity Test}

Table 4 indicates the probability values of $p=0.1327$ and 0.1325 both are greater than 0.05 indicate the presence of homoscedastic residuals. So there exists no problem of heteroskedasticty.

Table 4: Heteroskedasticity Output

\begin{tabular}{lcll}
\hline \multicolumn{4}{c}{ Heteroskedasticity Test: Breusch-Pagan-Godfrey } \\
\hline F-statistic & 1.7027 & Prob. F(5,416) & 0.1327 \\
Obs*R-squared & 8.4632 & Prob. Chi-Square(5) & 0.1325 \\
Scaled explained SS & 20.8327 & Prob. Chi-Square(5) & 0.0009 \\
\hline
\end{tabular}

\subsection{Hausman Test}

To choose the appropriate model between fixed effects model and random effects model, Hausman test helps to make the decision. Table 5 shows the outcome of Hausman test.

Table 5: Hausman Test

\begin{tabular}{lccc}
\hline Test Summary & Chi-Sq. df & Chi-Sq. Statistic & Prob. \\
\hline Cross Section Random & 5 & 36.01 & 0.000 \\
\hline ROA & Fixed & Random & Difference \\
\hline Age of Firm & -0.0653 & -0.0797 & -0.0145 \\
Log of Total Assets & -2.7005 & -0.7151 & 1.9853 \\
Fixed Asset Utilization & 0.0549 & 0.0640 & 0.0091 \\
Sponsor Shareholding & -0.0870 & -0.0424 & 0.0446 \\
Govt. Shareholding & -0.0544 & -0.0482 & 0.0062 \\
\hline
\end{tabular}

The output through conducting Hausman test indicates the probability value of 0.000 which is less than 0.05 what means fixed effects model is appropriate for the test.

\subsection{Fixed Effects Model}

$R$ squared value and adjusted $R$ squared value are $20.01 \%$ and $11.37 \%$ respectively. The $F$ statistic value of the test is 19.01 indicating the probability value of 0.000 which is robust and suggests that the relationship between the dependent and independent variables is significantly linear. The results show that only fixed asset utilization has positive impact while age of firm, 
log of total assets as size, sponsor shareholding, and government shareholding have negative impact on profitability. The overall findings indicate that log of total assets, fixed asset utilization, sponsor shareholding have significant impact at $1 \%$ level of significance on the profitability of the firm.

Table 6: Fixed Effect Model

\begin{tabular}{lccc}
\hline Return on Assets & Coeff. & t-Statistic & Prob. \\
\hline Constant & 33.8011 & 4.27 & 0.000 \\
Age of Firm & -0.0653 & -1.38 & 0.169 \\
Log of Total Assets & -2.7005 & -2.84 & $0.005^{*}$ \\
Fixed Asset Utilization & 0.0549 & 5.46 & $0.000^{*}$ \\
Sponsor Shareholding & -0.0870 & -4.74 & $0.000^{*}$ \\
Govt. Shareholding & -0.0544 & -1.42 & 0.156 \\
\hline significant at 1\% level of significance & & & \\
& & & \\
\hline R-squared & 0.2001 & $\mathrm{~F}(5,380)$ & 19.01 \\
Adj. R-squared & 0.1137 & Prob > F & 0.0000 \\
\hline
\end{tabular}

Age has negative impact on the profitability of firms supporting the findings of Oyelade (2019), Pervan et al., (2017), Akben-Selcuk (2016) but differing the findings of Ilaboya and Ohiokha (2016), Pagano and Schivardi (2003),

Log of total assets which indicate size of firm has significant and significant impact on the profitability supporting Kartikasari and Merianti (2016) but varying from the findings of Isık et al. (2017), John and Adebayo (2013), Pagano and Schivardi (2003)

Fixed asset utilization has significant positive impact on the profitability of firm varying from the findings of Warrad and Omari (2015), Okwo et al. (2012)

Sponsor shareholding has significant negative impact on the profitability of firm varying from the findings of Makhlouf et al. (2017) and government shareholding has also negative but insignificant impact on the profitability of firm partially supporting the findings of Mollah et al. (2012).

\section{LEARNING EFFECT AND SIZE EFFECT}

\subsection{Does Business Firm Learn Overtime?}

All the chosen companies listed on DSE under engineering industry were divided into four quartiles according to age and sorted from younger firms to older firms. Each quartile indicates the average age of the firms under assigned category for the period of 2000-2019. The first quartile (Q1) represents the average age of youngest firms and fourth quartile (Q4) represents the average age of oldest firms by following the pattern of $Q_{1}<Q_{2}<Q_{3}<Q_{4}$ where $Q$ stands for Quartile according to the average ages in years shown on Table 7.

Table 7: Age Quartile

\begin{tabular}{cc}
\hline Quartile & Average Age in Years \\
\hline Q1 & 12 \\
Q2 & 22 \\
Q3 & 29 \\
Q4 & 44 \\
\hline
\end{tabular}

Figure 1 helps to understand the learning effect on the firms. At Q1, the youngest stage, a firm makes on an average ROA of $5.06 \%$. At Q2, the firm grows older but faces most troubles and loses profitability. The average ROA reduces to $1.47 \%$ what is an indication of not learning by getting older. 
Figure 1: Profitability of Firm as Learning Effect

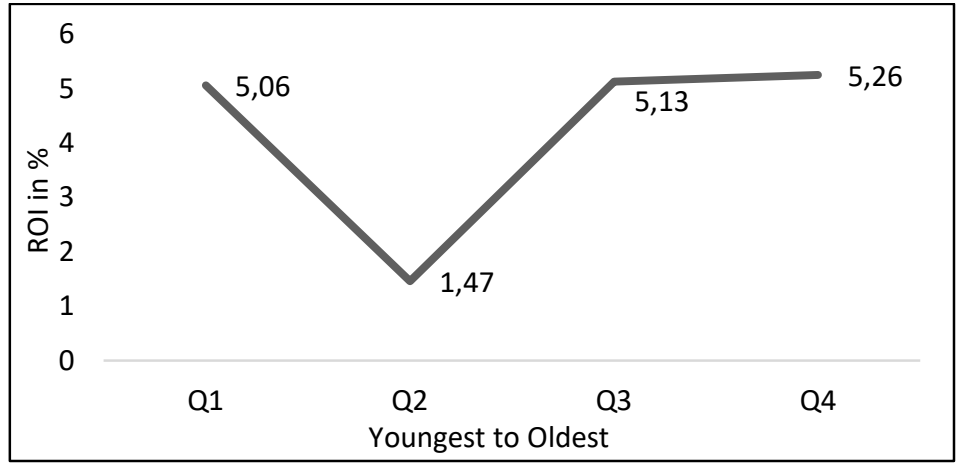

Later at Q3, the firm tries to learn, understands the mistakes and generates higher profits with an average ROA of 5.13\%. At Q4, the oldest stage, the firm outperforms the market by adding more profitability resulting to an average ROA of 5.26\%. But the growth of profitability at the oldest stage isn't the same as immediate previous stage.

Figure 2: Learning Effect of Firm Overtime

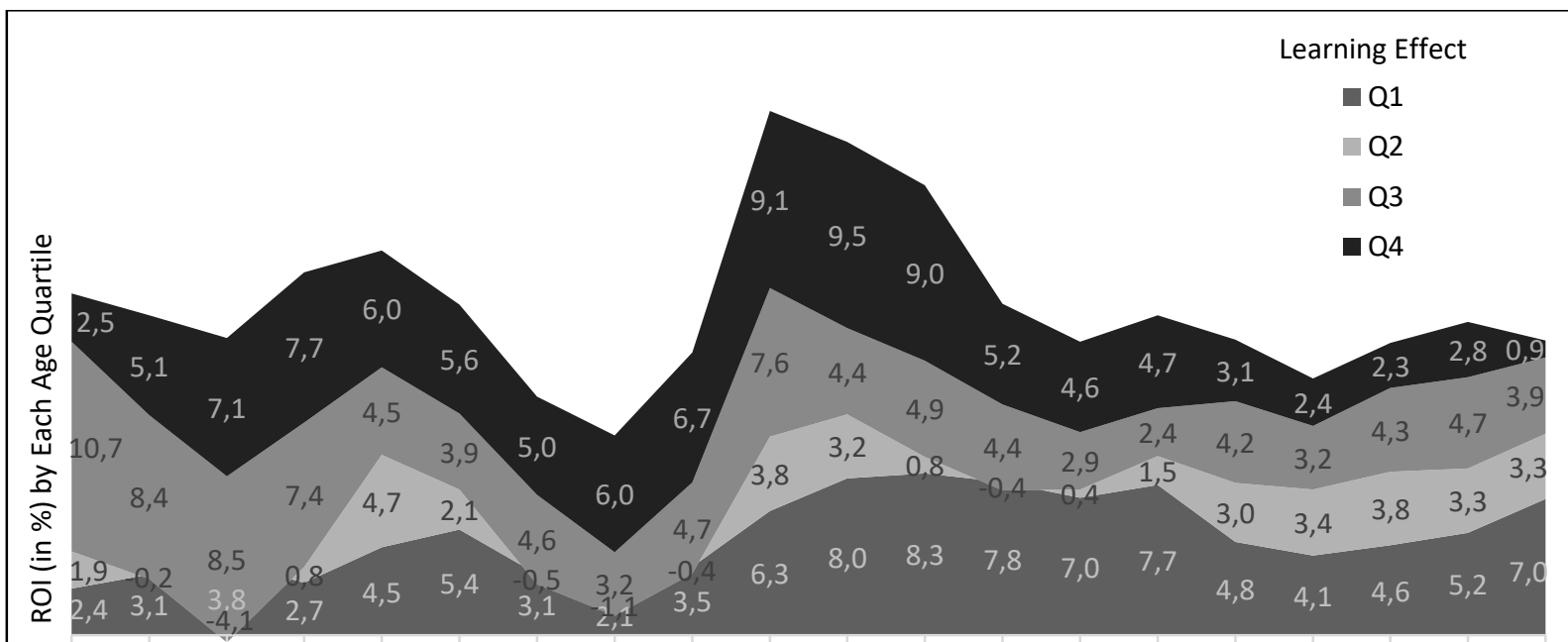

20002001200220032004200520062007200820092010201120122013201420152016201720182019

Figure 2 clarifies whether the business firm learns to maximize the profitability as a result of learning effect. The individual average returns on assets in Q3 and Q4 are higher than the individual returns on assets in Q1 and Q2 but no clear movement pattern is strongly seen. Thus a mixed view is received regarding the learning effect on the performance of firms under engineering industry of Bangladesh. This observation varies from the findings of Coad, Daunfeldt and Halvarsson (2014) but supports the findings of Akben-Selcuk (2016).

\subsection{Does the Size of Firm Increase Profitability?}

All the chosen companies listed on DSE under engineering industry were divided into four quartiles according to the total assets as a measurement of size and sorted from smaller firms to larger firms in size. Each quartile indicates the average size of the firms under assigned category for the period of 2000-2019. The first quartile (Q1) represents the firms in smallest size and fourth quartile (Q4) represents the firms in largest size by following the pattern of $Q 1<Q_{2}<Q_{3}<Q_{4}$ where $Q$ stands for Quartile according to the average sizes shown on Table 8. 
Table 8: Size Quartile

\begin{tabular}{cc}
\hline Size & Mean Size in BDT Billion \\
\hline Q1 & 0.23 \\
Q2 & 0.95 \\
Q3 & 2.32 \\
Q4 & 9.17 \\
\hline
\end{tabular}

Figure 3 helps to understand the size effect on the firms. At Q1, the smallest stage, a firm makes on an average ROA of 3.56\%. At Q2, the firm grows larger in size and increases profitability to an average ROI of $3.73 \%$.

Figure 3: Profitability of Firm as Size Effect

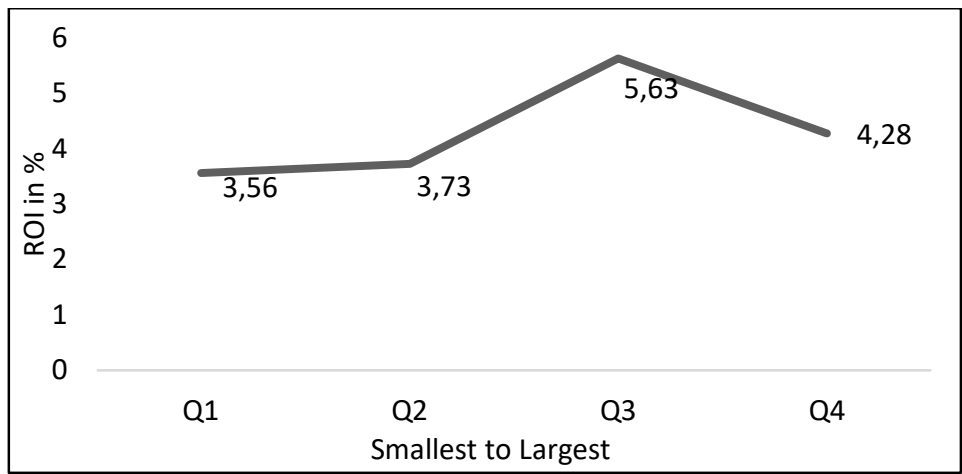

Later at Q3, the firm keeps growing in size, understands business strategies better and generates higher average ROA of 5.63\%. Firm outperforms the market at Q3 and the consecutive higher returns on assets indicate the impacts of size effect. At Q4, the largest stage, the firm loses the profitability resulting to an average ROA of $4.28 \%$. At Q4, the firms face most troubles. The bigger in size the firms grow, the firms successfully maintains the consistency on making higher profitability except Q4. Owing to organizational inertia, firms can't utilize the size advantage on making higher profitability in Q4.

\section{Figure 4: Size Effect of Firm Over time}

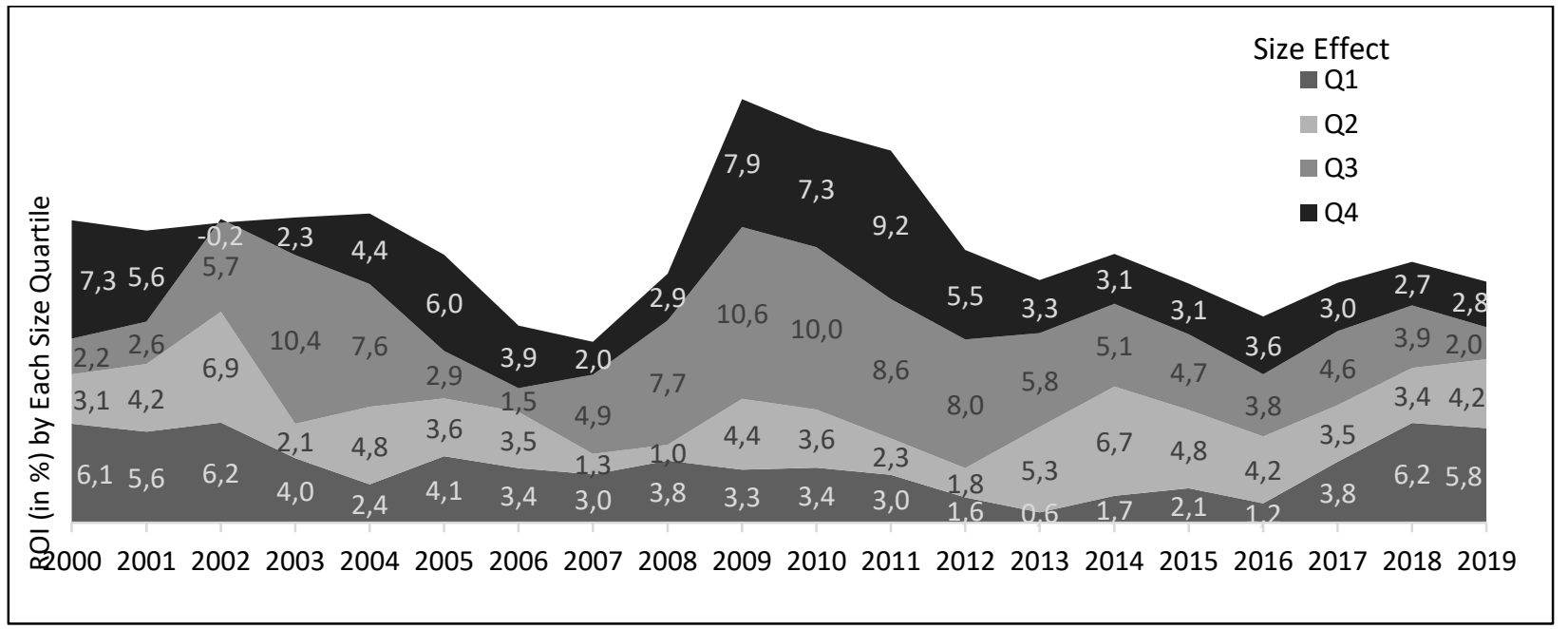


Figure 4 clarifies whether the business firm can utilize its size to maximize the profitability as a result of size effect. The individual average returns on assets in Q3 and Q4 are higher than the individual returns on assets in Q1 and Q2. Thus in size effect here also a mixed view is experienced on the performance of firms under engineering industry of Bangladesh in Figure 4. This observation differs from the findings of llaboya and Ohiokha (2016), Pagano and Schivardi (2003) but supports the findings of Abeyrathna and Priyadarshana (2019), Kartikasari and Merianti (2016).

\section{CONCLUSION}

In this paper, the effects of age, size, fixed asset utilization, sponsor and government shareholdings on the profitability of the firm are investigated by analyzing the data of 37 companies listed on Dhaka Stock Exchange for a period of 2000 to 2019 . The result is robust and contextual as per the probable outcomes assumed from previous study. The paper found that size, fixed asset utilization, and sponsor shareholding have strong impacts on the return on assets of the firm. There exists positive relationship of fixed asset utilization on the profitability and negative relationship of age, size, sponsor and government shareholdings on the profitability of the chosen firms. For the economy of Bangladesh, engineering industry plays a vital role by providing products from capital intensive projects to the consumer goods. Proper asset utilization and operational excellence from management of the company help to continue learning progress. The analysis indicates that age effect and size effect influence the profitability of firms in a mixed movement due learning process and organizational inertia.

\section{POLICY IMPLICATIONS}

The paper clarifies some key points. For making an investment into the firm under engineering industry, an investor should focus more on the size, fixed asset utilization, sponsor shareholding pattern of the firm. As the firms performs better in youngest and oldest periods than in middle periods, an investor should try to make investment into the newest and the oldest firms for minimizing investment risks and maximizing profitability. Again the investors should prefer the larger firms than the smaller firms in terms of size for making investment decision. But they should avoid making investment in the largest firms as the profitability of reduces at this stage because organizational inertia. Economic activities are highly influenced by the engineering industry as this industry correlates the economy. For proliferation, the government should introduce a new policy regarding fair distribution among different shareholding patterns as it impacts the profitability of the firm through maintaining efficiency. The management of the firm should focus on it too. The engineering industry strongly needs skilled manpower and more expertise. Firms should minimize the operating expenses, increase the size, distribute ownership structure in nearby equal proportionate for getting best position in changing the competitive structure of the engineering industry of Bangladesh.

\section{REFERENCES}

Abeyrathna, S., and Priyadarshana, A. (2019). Impact of Firm size on Profitability. International Journal Of Scientific And Research Publications (IJSRP), 9(6), p9081. doi: 10.29322/ijsrp.9.06.2019.p9081

Akben-Selcuk, E. (2016). Does Firm Age Affect Profitability? Evidence from Turkey. International Journal Of Economic Sciences, V(3). doi: 10.20472/es.2016.5.3.001

Ani, M. (2014). Effects of Assets Structure on the Financial Performance: Evidence From Sultanate of Oman. Journal Of US-China Public Administration, 11(2), 170-179.

Becker-Blease, J., Kaen, F., Etebari, A., and Bauman, H. (2010). Employees, firm size and profitability in U.S. manufacturing industries. Investment Management And Financial Innovations, 7(2), 7-23.

Cho, D., and Kim, J. (2007). Outside Directors, Ownership Structure and Firm Profitability in Korea. Corporate Governance: An International Review, 15(2), 239-250. doi: 10.1111/j.1467-8683.2007.00557.x

Coad, A. (2016). Firm age: a survey. Journal Of Evolutionary Economics, 28(1), 13-43. doi: 10.1007/s00191-016-0486-0

Coad, A., Daunfeldt, S., and Halvarsson, D. (2015). Bursting into Life: Firm Growth and Growth Persistence by Age. SSRN Electronic Journal. doi: $10.2139 /$ ssrn. 2616759

Cowling, M., and Tanewski, G. (2018). On the productive efficiency of Australian businesses: firm size and age class effects. Small Business Economics, 53(3), 739-752. doi: 10.1007/s11187-018-0070-0

Fareed, Z., Ali, Z., Shahzad, F., Nazir, M., and Ullah, A. (2016). Determinants of Profitability: Evidence from Power and Energy Sector. Studia Universitatis Babe-Bolyai Oeconomica, 61(3), 59-78. doi: 10.1515/subboec-2016-0005 
Hui, H., Radzi, C., Jenatabadi, H., Kashim, F., and Radu, S. (2013). The Impact of Firm Age and Size on the Relationship among Organizational Innovation, Learning, and Performance: A Moderation Analysis in Asian Food Manufacturing Companies. Interdisciplinary Journal Of Contemporary Research Business, 5(4), 166-174.

Ilaboya, O., and Ohiokha, I. (2016). Firm Age, Size and Profitability Dynamics: A Test of Learning by Doing and Structural Inertia Hypotheses. Business And Management Research, 5(1), 29-39. doi: 10.5430/bmr.v5n1p29

Isık, O., Aydın Unal, E., and Unal, Y. (2017). THE EFFECT OF FIRM SIZE ON PROFITABILITY: EVIDENCE FROM TURKISH MANUFACTURING SECTOR. Pressacademia, 6(4), 301-308. doi: 10.17261/pressacademia.2017.762

John, A., and Adebayo, O. (2013). Effect of Firm Size on Profitability: Evidence from Nigerian Manufacturing Sector. Prime Journal Of Business Administration And Management (BAM), 3(9), 1171-1175.

Kartikasari, D., and Merianti, M. (2016). The Effect of Leverage and Firm Size to Profitability of Public Manufacturing Companies in Indonesia. International Journal Of Economics And Financial Issues, 6(2), 409-413.

Liu, K. (2018). Government Ownership in Listed Firms Around the World. Studies In Business And Economics, 13(2), 131-146. doi: 10.2478/sbe2018-0025

Light Engineering Sector Bangladesh. (2020). Retrieved 8 May 2020, from http://www.projectsprofile.com/info/potential_one.html

Makhlouf, M., Laili, N., Basah, M., and Ramli, N. (2017). Board of Directors' Effectiveness and Firm Performance: Evidence from Jordan. Research Journal Of Finance And Accounting, 8(18), 23-34.

Mollah, S., Al Farooque, O., and Karim, W. (2012). Ownership structure, corporate governance and firm performance. Studies In Economics And Finance, 29(4), 301-319. doi: 10.1108/10867371211266937

Navaretti, G., Castellani, D., and Pieri, F. (2012) (pp. 1-30). Dhaka: European Commission's Seventh Framework Programme. Retrieved from https://www.bruegel.org/wp-content/uploads/2015/09/efige_wp60_3108121.pdf

Okwo, I., Okelue, U., and Nweze, A. (2012). Investment in Fixed Assets and Firm Profitability: Evidence from the Nigerian Brewery Industry. European Journal Of Business And Management, 4(20), 10-18.

Oyelade, A. (2019). The Impact of Firm Size on Firms Performance in Nigeria: A Comparative Study of Selected Firms in the Building Industry in Nigeria. Asian Development Policy Review, 7(1), 1-11. doi: 10.18488/journal.107.2019.71.1.11

Pagano, P., and Schivardi, F. (2003). Firm Size Distribution and Growth*. Scandinavian Journal Of Economics, 105(2), 255-274. doi: 10.1111/1467-9442.t01-1-00008

Pervan, M., Pervan, I., and Ćurak, M. (2017). The Influence of Age on Firm Performance: Evidence from the Croatian Food Industry. Journal Of Eastern Europe Research In Business And Economics, 1-9. doi: 10.5171/2017.618681

Rizqia, D., Aisjah, S., and Sumaiti. (2013). Effect of Managerial Ownership, Financial Leverage, Profitability, Firm Size, and Investment Opportunity on Dividend Policy and Firm Value. Research Journal Of Finance And Accounting, 4(11), $120-130$.

Stančić, P., Čupić, M., and Obradović, V. (2014). Influence of board and ownership structure on bank profitability: evidence from South East Europe. Economic Research-Ekonomska Istraživanja, 27(1), 573-589. doi: 10.1080/1331677x.2014.970450

Warrad, L., and Omari, R. (2015). The Impact of Turnover Ratios on Jordanian Services Sectors' Performance. Journal Of Modern Accounting And Auditing, 11(2), 78-85. doi: 10.17265/1548-6583/2015.02.001 